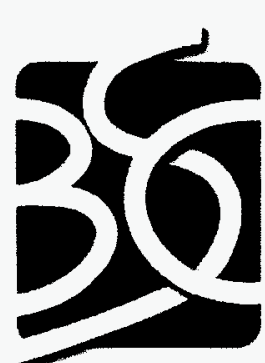

BECHTEL SAIC companutuc
QA: QA

TDR-WHS-Cl-000001 REV 00

MOL . 20020627.0288

June 2002

\title{
Data Qualification Report: Data Qualification Report for 1991 1:1200 Scale Topographic Maps for Use on the Yucca Mountain Project
}

By

Matthew F. Knop, Terry A. Grant, and Robert W. Bonisolli

Prepared for:

U.S. Department of Energy

Yucca Mountain Site Characterization Office

P.O. Box 364629

North Las Vegas, Nevada 89036-8629

Prepared by:

Bechtel SAIC Company, LLC

1180 Town Center Drive

Las Vegas, Nevada 89144

Under Contract Number

DE-AC08-01RW 12101 


\section{DISCLAIMER}

This report was prepared as an account of work sponsored by an agency of the United States Government. Neither the United States Government nor any agency thereof, nor any of their employees, nor any of their contractors, subcontractors or their employees, makes any warranty, express or implied, or assumes any legal liability or responsibility for the accuracy, completeness, or any third party's use or the results of such use of any information, apparatus, product, or process disclosed, or represents that its use would not infringe privately owned rights. Reference herein to any specific commercial product, process, or service by trade name, trademark, manufacturer, or otherwise, does not necessarily constitute or imply its endorsement, recommendation, or favoring by the United States Government or any agency thereof or its contractors or subcontractors. The views and opinions of authors expressed herein do not necessarily state or reflect those of the United States Government or any agency thereof. 
Prepared by:

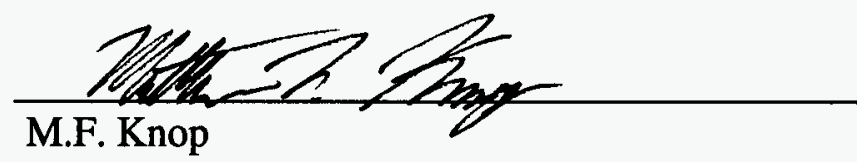

Chairperson
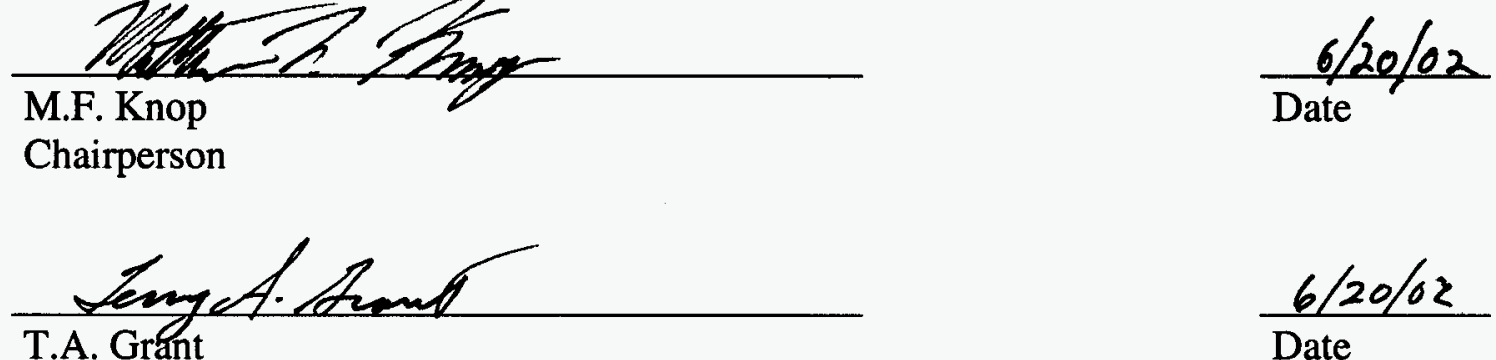

T.A. Grant

Technical Representative

$\frac{6 / 20 / 02}{\text { Date }}$

Mobent W. Bonsoll.

R.W. Bonisolli

$6 / 20 / 02$

Technical Representative

Date

Approved by:

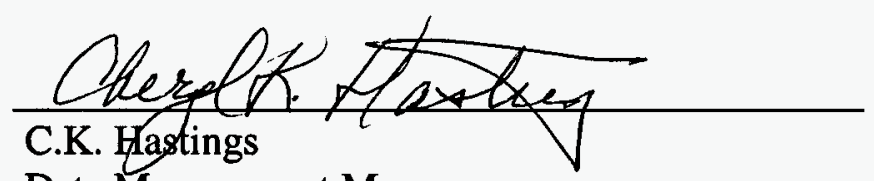

Data Management Manager
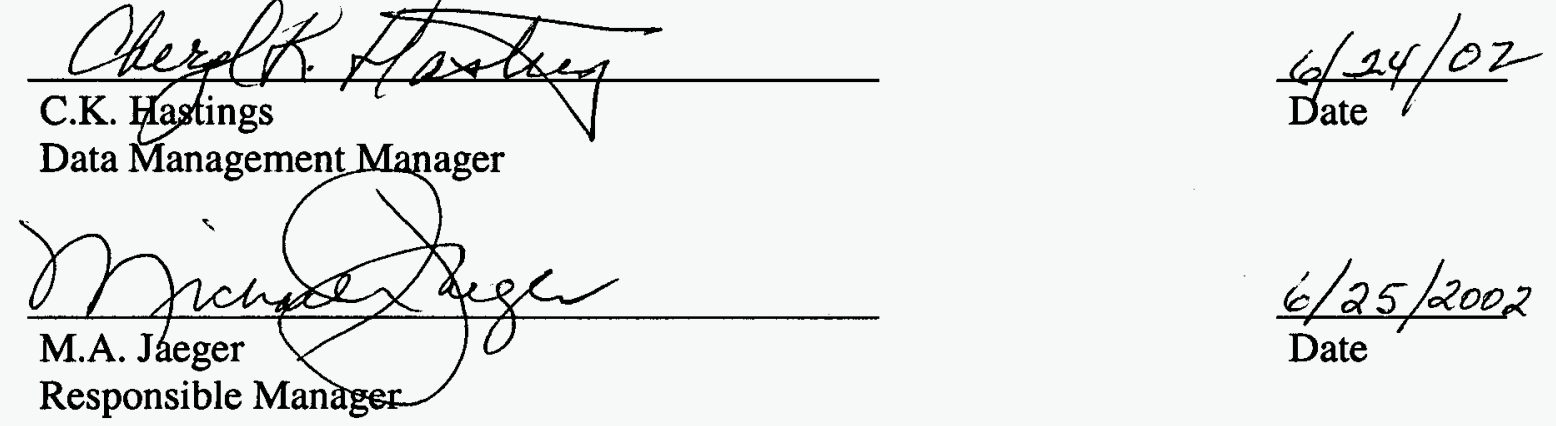


\section{EXECUTIVE SUMMARY}

This Data Qualification Report (DQR) is prepared in accordance with the provisions of AP-SIII.2Q, Rev. 0, ICN 3, Qualification of Unqualified Data and the Documentation of Rationale for Accepted Data and Data Qualification Plan for 1991 Topographic Maps 1:1200 Scale for use on the Yucca Mountain Project, DQP-WHS-CI-000001, Rev. 00 (BSC 2002a). This DQR presents an evaluation of a set of 90 topographic sheets at 1:1200 scale (and an associated electronic file) that covers an approximate 18 square mile area surrounding the proposed Yucca Mountain Project repository surface facilities location in Midway Valley, Nevada. These maps, that require qualification, are now being used to determine the physical characteristics of watershed sub-areas, interconnecting channels, and drainage channel crosssections for hydrologic engineering studies of the north portal pad and vicinity. The result of this effort is to qualify one data tracking number (DTN) containing the electronic version of the mapping data. This DTN is: MO9906COV98462.000. Coverage: TOPO2FTS.

The underlying quality assurance (QA) issue associated with these topographic maps is that the maps were originally designated as not for use in the design of items important to safety, waste isolation, and/or of programmatic importance. The maps were therefore generated outside the U.S. Department of Energy Office of Civilian Radioactive Waste Management (OCRWM) QA program.

Based on a comparison with corroborating information, this report concludes that the topographic maps are qualified. The comparison found that the mapping was reasonably accurate when compared with other mapping and survey data within the coverage area of the maps. Relative map accuracy was found to be very good and suitable for the hydrologic engineering studies being considered. Absolute accuracy is good but could not be demonstrated to comply with national map accuracy standards. Point locations that require high absolute accuracy should be determined with standard surveying techniques rather than being scaled from the topographic map. 
INTENTIONALLY LEFT BLANK 


\section{CONTENTS}

Page

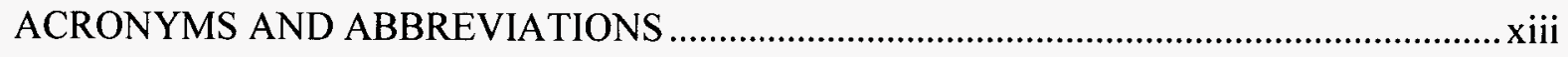

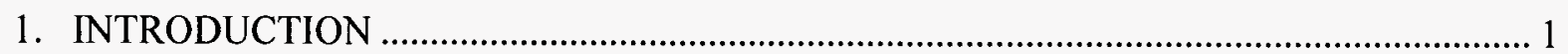

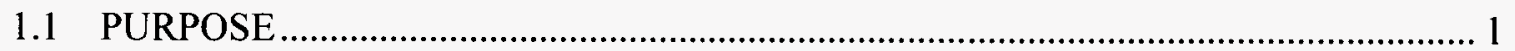

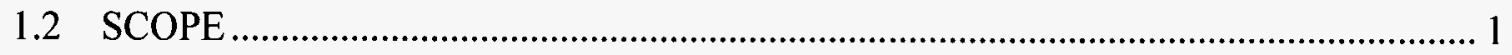

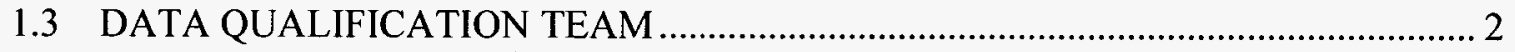

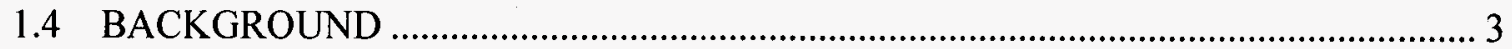

2. QUALIFICATION METHODS ................................................................................ 4

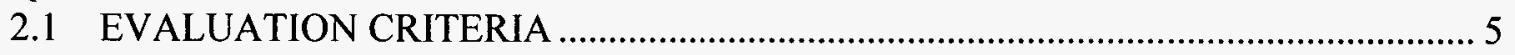

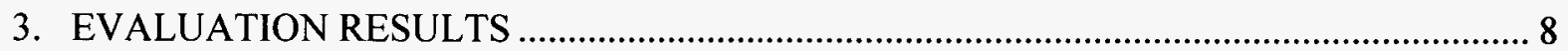

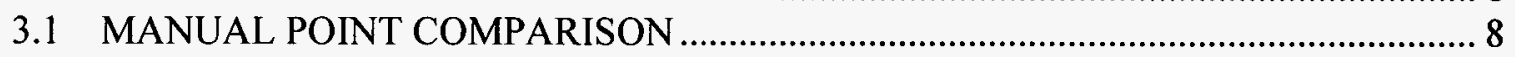

3.2 COMPARISON OF DIGITAL ELEVATION MODELS ......................................... 9

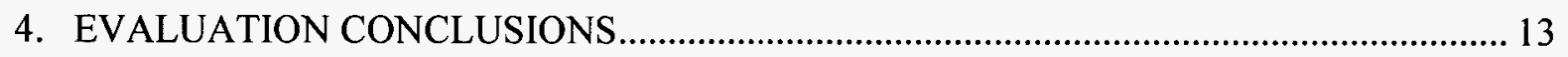

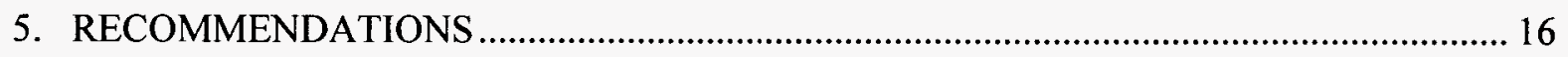

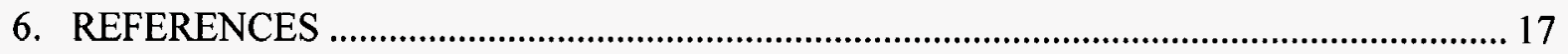

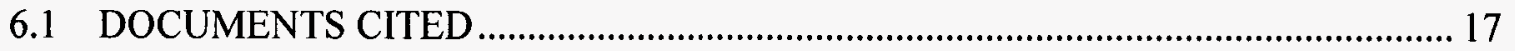

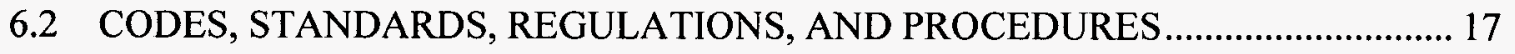

6.3 SOURCE DATA, LISTED BY DATA TRACKING NUMBER …........................... 17

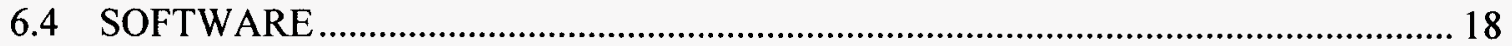

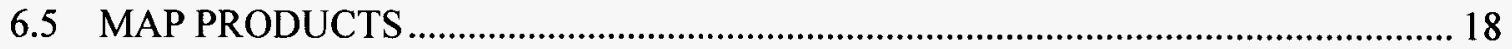

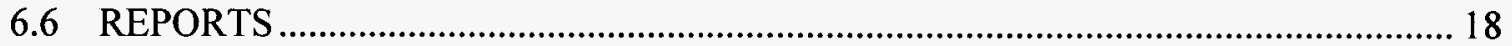

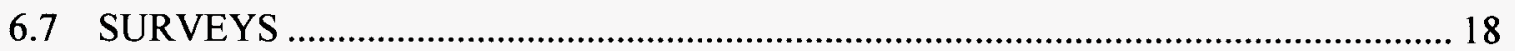




\section{INTENTIONALLY LEFT BLANK}




\section{FIGURES}

Page

1. Accuracy limitations when comparing two sources. .................................................... 5

2. Visual representation of the DEM comparison process for the area identified in Table 4. The middle layer is subtracted from the upper layer to produce a representation of the difference or variance (lower layer) between the topographic surfaces represented by the two models.

3. Comparison of profiles across area in Figure 2 
INTENTIONALLY LEFT BLANK 


\section{TABLES}

Page

1. Sources used by the Data Qualification Team ................................................................. 7

2. Manual comparison of point data between 1:1200 scale map and corroborating

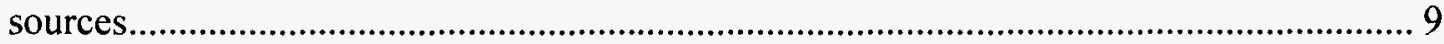

3. Digital comparison of elevations from the 1:1200 DEM with elevations from DEMs from corroborating sources for selected boreholes. All values are given in feet, horizontal coordinates are State Plane coordinates. 11

4. Results of DEM Comparison 


\section{INTENTIONALLY LEFT BLANK}




\section{ACRONYMS AND ABBREVIATIONS}

\begin{tabular}{|c|c|}
\hline $\begin{array}{l}\text { AEC } \\
\text { AMR }\end{array}$ & $\begin{array}{l}\text { Atomic Energy Commission } \\
\text { Analysis/Model Report }\end{array}$ \\
\hline $\begin{array}{l}\text { DEM } \\
\text { DOE } \\
\text { DTN }\end{array}$ & $\begin{array}{l}\text { Digital Elevation Model } \\
\text { U.S. Department of Energy } \\
\text { data tracking number }\end{array}$ \\
\hline$E G \& G$ & EG \& G Energy Measurements, Inc. \\
\hline $\begin{array}{l}\text { GIS } \\
\text { GPS }\end{array}$ & $\begin{array}{l}\text { Geographic Information System } \\
\text { global positioning system }\end{array}$ \\
\hline $\mathrm{H} \& \mathrm{~N}$ & Holmes \& Narver \\
\hline $\begin{array}{l}\text { NNWSI } \\
\text { NOAA } \\
\text { NRC }\end{array}$ & $\begin{array}{l}\text { Nevada Nuclear Waste Storage Investigation } \\
\text { National Oceanic and Atmospheric Administration } \\
\text { U.S. Nuclear Regulatory Commission }\end{array}$ \\
\hline OCRWM & Office of Civilian Radioactive Waste Management \\
\hline $\begin{array}{l}\text { QA } \\
\text { QAGR } \\
\text { QARD }\end{array}$ & $\begin{array}{l}\text { Quality Assurance } \\
\text { Quality Assurance Grading Report } \\
\text { Quality Assurance Requirements Document }\end{array}$ \\
\hline RSN & Raytheon Services Nevada \\
\hline $\begin{array}{l}\text { TDMS } \\
\text { TINS }\end{array}$ & $\begin{array}{l}\text { Technical Data Management System } \\
\text { Triangular Irregular Networks }\end{array}$ \\
\hline USGS & U.S. Geological Survey \\
\hline WMPO & Waste Management Project Office \\
\hline YMP & Yucca Mountain Project \\
\hline
\end{tabular}




\section{INTENTIONALLY LEFT BLANK}




\section{INTRODUCTION}

\subsection{PURPOSE}

This DQR uses the corroborating data method specified in Attachment 2 of AP-SIII.2Q, to qualify one DTN: MO9906COV98462.000 containing topographic mapping data that covers an approximate 18 square mile area surrounding the proposed Yucca Mountain Project repository surface facilities location in Midway Valley, Nevada. This DQR considers acquired mapping data generated by a subcontractor. The data set consists of an electronic file and a hard-copy set of 90 topographic sheets at 1:1200 scale with a two-foot contour interval. The planning document for this qualification is BSC (2002a), which outlines a qualification process emphasizing the method of corroboration.

The underlying QA issues associated with this set of mapping data are that the Quality Assurance Grading Report (QAGR) Aerial Mapping of a Portion of the Yucca Mountain Site Characterization Project Area, RSN-GR-022, prepared for this work in 1991, indicated that the mapping would not be used for the design of items important to safety or waste isolation and was not considered to be of programmatic importance. Therefore, the mapping was not developed under the requirements of the Quality Assurance Requirements and Description (QARD), $\mathrm{DOE} / \mathrm{RW}-0333 \mathrm{P}$, and is considered unqualified. These maps are now being used to determine the physical characteristics of watershed sub-areas, interconnecting channels, and drainage channel cross-sections to calculate the maximum-flood elevation in Midway Valley. This will determine the height of the pad on which the proposed Waste Handling Building and associated facilities will sit and, therefore, the mapping would require qualification. This qualification effort was performed to determine if the mapping data contained in the subject DTN meet YMP requirements for unrestricted use in YMP work products.

In accordance with Attachment 1 of procedure AP-3.15Q, Rev. 3, ICN 2, Managing Technical Product Inputs, and pursuant to a review of Preliminary Hydrologic Engineering Studies for the North Portal Pad and Vicinity, Rev. 0, ANL-EBS-MD-000060 (BSC 2002b), using the information, it has been determined that the unqualified data are used in the evaluation of factors that are important to safety, but are not principal factors as defined by AP-3.15Q. Therefore, in accordance with procedure AP-SIII.2Q, Section 5.1.1, concurrence is not required by the Yucca Mountain Site Characterization Office Assistant Manager, Office of Project Execution.

Data qualified in this DQR may either be retained in the original DTNs or placed in new DTNs generated as a result of the evaluation. The appropriateness and limitations (if any) of the data with respect to intended use are addressed in this report.

\subsection{SCOPE}

This DQR presents an evaluation of data contained in DTN MO9906COV98462.000. The DTN represents a specific electronic file containing topographic data in the Technical Data Management System (TDMS). This DTN is used in BSC (2002b). The emphasis of this DQR is to evaluate the accuracy and suitability of the topographic data contained in the DTN listed above for unrestricted use on the YMP. 


\subsection{DATA QUALIFICATION TEAM}

The Responsible Manager for this data qualification task is Michael A. Jaeger.

\section{Chairperson}

Matthew F. Knop: Mr. Knop is designated the Chairperson for this Data Qualification Team. Mr. Knop is a subject matter expert in the field of Geographic Information Systems (GIS). He has bachelor of science degrees in Geology and in Geography/Remote Sensing (Northern Arizona University) and a master of science degree in Geography/Remote Sensing (University of Utah). In his 11 years of experience he has worked on various projects pertaining to Environmental Impact Statements, risk assessment, water resource issues, dust mitigation projects, transportation planning, environmental modeling, and several federal and state projects in which data under his purview were subject to intense legal scrutiny. He has been an adjunct professor at the Community College of Southern Nevada for the past 3 years teaching GIS and Remote Sensing classes. Mr. Knop has had no involvement with the collection or processing of the YMP data being evaluated in this DQR.

\section{Technical Representatives}

Terry A. Grant: $\quad$ Mr. Grant is a Data Qualification Team member. He has a master of science degree in Geology (University of Nevada, Reno, 1974). Mr. Grant is an engineering geologist with experience in site studies and the management of large multidisciplinary projects. He has been responsible for conceiving site selection methodologies and for implementing data gathering studies for high-level nuclear waste repositories and nuclear power plants requiring QA programs. He has supervised or conducted investigations involving the use of remote sensing and photogrammetric applications including studies of site geology, active faulting, seismology, geologic hazards, energy and mineral resources, and ground-water hydrology. Mr. Grant has a varied background in other remote sensing and photogrammetric applications including serving as an army remote sensing specialist and Non-Commissioned Officer in charge of the imagery interpretation section of an intelligence unit in Vietnam. Mr. Grant has had no involvement with the collection or processing of the YMP data being evaluated in this DQR.

Robert W. Bonisolli: Mr. Bonisolli has a bachelor of science degree in Marine Engineering from Massachusetts Maritime Academy (1981) and 21 years experience in nuclear power plant construction and operational support. He has worked in all phases of the data qualification process (i.e., developing qualification plans, performing qualification actions, interfacing with the DOE, U.S. Geological Survey (USGS), national laboratories, etc.). Responsibilities have included reviewing listings of License Application technical products and determining associated parameters/data with 
affected organizations, researching and identifying supporting information to support parameter/data verification and pedigree requirements, developing documentation to ensure QARD and regulatory requirements are met, and developing checklists and performing verification actions in accordance with applicable administrative procedures. Mr. Bonisolli has had no involvement with the collection or processing of these data.

\subsection{BACKGROUND}

The topographic data reported in the unqualified DTN MO9906COV98462.000 were developed in 1991, under QAGR, RSN-GR-022, to provide greater detail and accuracy than existing maps and as a reference tool for use in the design layout of surface facilities. At that time, it was determined that the data did not need to be collected under the controls of the QARD because the actual layout of the surface facilities would be conducted in the field using traditional survey methods under YMP procedures. The work was controlled under Job Package 91-8, 07-26-91, Aerial Mapping.

A mapping project of this type consists of four steps:

Ground Control

Aerial Photography

Photogrammetric Processing

Final Product Preparation

Ground Control-A set of control points is established across the area to be mapped and marked with panels so as to be visible on the aerial photography. The control points are surveyed with traditional methods and are used to correct scale changes in the photography and to tie the mapping to standard coordinate systems (e.g., latitude/longitude, state plane coordinates) and elevation control (e.g., mean sea level). The ground control for this mapping project was carried out by a Yucca Mountain contractor, Raytheon Services Nevada (RSN), during May and June of 1991. The requirements for the photogrammetric processing called for third-order survey accuracy. (The survey notes for this work are located in Records Package MOY-940825-07-01.)

Aerial Photography-High-quality stereoscopic aerial photography of the map area is required for the production of topographic maps. The aerial photography for this mapping project was flown by a Nevada Test Site contractor EG\&G Energy Measurements, Inc. (EG\&G) on August 26-27, 1991. The mission used a Citation aircraft equipped with a Wild RC-10 camera (serial \#13050) with a $153 \mathrm{~mm}$ (6-inch) lens and Aerocolor film. The mission was flown at a nominal height of 3000 feet above the terrain. The film was processed in the EG\&G laboratory and shipped to a subcontractor for the preparation of the maps.

Photogrammetric Processing-In general terms, this step involves using the ground control to correct scale variations in the photography caused by variations in height of the aircraft; by aircraft yaw, pitch, and roll; and other factors. The ground control is also used to establish absolute elevation control and to tie the map to standard coordinate systems. Contours are then generated by using the corrected stereoscopic image of the ground surface to trace out lines of equal elevation. This process has been in use since the 1930s and is well established. The only 
change is the correction and contouring processes that were previously accomplished by optical and mechanical means are now (and in 1991) done using computer controlled digital systems. In modern systems, manual tracing of contours is replaced by contouring that is generated from a digital elevation model (DEM) that is still based on elevation data derived from the stereoscopic image. For this mapping project, EG\&G qualified and solicited bids from two contractors to produce the maps. The Orthoshop-Tucson (1121 West Grant Road, Suite 401, Tucson, Arizona, 85705) was selected for the project. In 1991, the Orthoshop was using Wild Aviolyt $\mathrm{BCl}$ and $\mathrm{BC} 2$ computer controlled precision analytical photogrammetric systems as their primary tool. The company indicated in their bid document that their system would locate basic information related to the datum of the maps, such as ground control points, photogrammetric control points, projection graticule and grid, with an accuracy of $0.25 \mathrm{~mm}$ or better, at map scale with respect to each other within each map sheet. In addition, ninety percent of all well-defined features would be located within $0.40 \mathrm{~mm}$ at map scale of their true position.

Final Product Preparation-The final step in the process is the production of the final products from the digital elevation model generated in the previous step. For this mapping project, the products were a copy of the digital model on magnetic tape and a set of conventional hard-copy contour maps. The hard-copy maps consist of a set of 90 sheets on mylar. An index map showing the location of the map sheets is located in the Yucca Mountain Site Characterization Project Site Atlas 1997 (DOE 1997).

\section{QUALIFICATION METHODS}

The qualification method of corroboration was used to assess the data covered by this DQR. The corroborating data method involves comparing different data sets to evaluate the consistency between sets of independently acquired data. As stated in AP-SIII.2Q, Attachment 2, the corroborating data approach may include comparisons of unqualified data with other unqualified data, as well as comparisons between unqualified and qualified data.

A requirement for using the corroboration method is that a sufficient quantity of corroborating data be available for comparison with the unqualified data set(s). As listed in Table 1, there are several independently acquired data sets that cover the area mapped by DTN MO9906COV98462.000. These sets are independent because they were generated at different times using different sets of photography and survey controls. It was judged by the Data Qualification Team that there were a sufficient number of corroborating data sets to successfully apply this method.

This DQR makes a distinction between the absolute and relative accuracy of topographic mapping. Absolute accuracy refers to how well a point is located with respect to standard external reference systems (e.g., latitude/longitude, state plane coordinates, mean sea level). The determination of absolute accuracy is dependent on a comparison of the mapped location of a point to the "true" location of the point determined by other methods. However, since all location methods are subject to accuracy limitations, the actual location of a point in space relative to the external reference systems can never be known with total accuracy. Relative accuracy refers to how well the surface represented by the topographic map or DEM models the shape of the actual ground surface in the field without reference to an external datum. Therefore, a map may have high relative accuracy if it portrays the shape of the land surface accurately, but 
may have low absolute accuracy if the elevations of points on the surface are uniformly in error by 20 feet with respect to mean sea level.

When comparing two maps or surveys, the cumulative accuracy of both sources must be taken into account. This is illustrated in Figure 1. As an example, if the vertical accuracy of topographic maps is one-half contour interval, then the indicated elevations of a given point on two maps with 10-foot and 2-contour intervals respectively may differ by as much as 6 feet $((10 / 2)+(2 / 2)=6)$ and still honor the accuracy requirements for the maps.

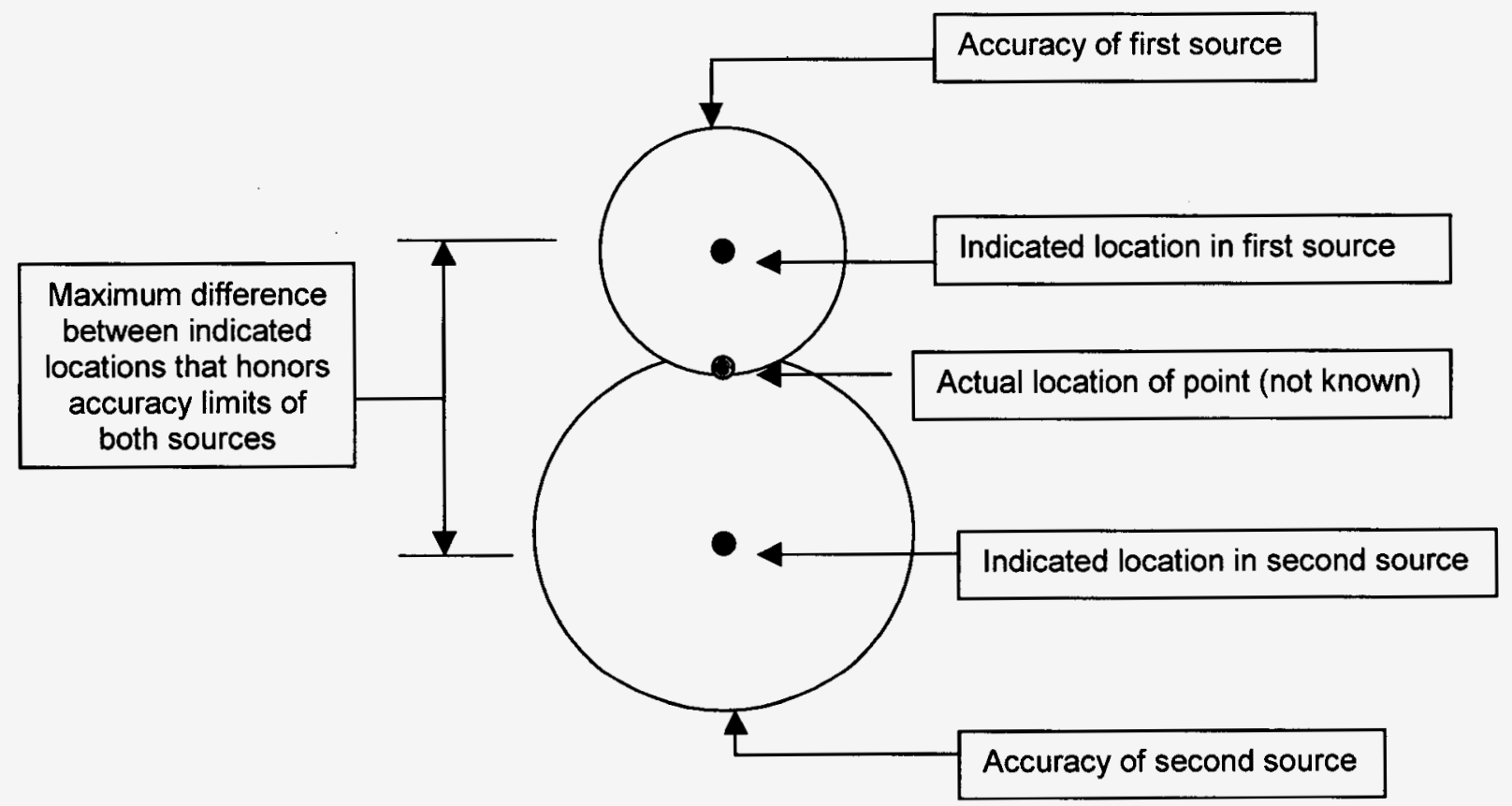

Figure 1. Accuracy limitations when comparing two sources.

\subsection{EVALUATION CRITERIA}

The unqualified data will be considered qualified based on consideration of the following evaluation criteria. These criteria were selected to incorporate the considerations in AP-SIII.2Q, Attachment 2; the applicable qualification process attributes listed in AP-SIII.2Q, Attachment 3; and the data-specific considerations identified in Section 3.

1. Are the data collection methods reasonable in view of standard measurement and instrumentation practice at the time the data were collected?

2. Are the qualifications of the personnel or organizations generating the data comparable to the qualification requirements of personnel generating similar data under the approved 10 CFR 63, Subpart G, program?

3. Are these data, or similarly collected data, generally accepted by the technical community for use in non-project applications? 
4. Does analysis of comparable qualified and unqualified data sets indicate a reasonable level of accuracy for the mapping products?

For the purposes of implementing Criteria 3 and 4, the Data Qualification Team selected the United States National Map Accuracy Standards used by the USGS as a benchmark for determining what constituted generally accepted standards for this type of work by the technical community. The following gives the relevant sections of the standards:

With a view to the utmost economy and expedition in producing maps that fulfill not only the broad needs for standard or principal maps, but also the reasonable particular needs of individual agencies, the Federal Government has defined the following standards of accuracy for published maps:

1. Horizontal accuracy. For maps on publication scales larger than $1: 20,000$, not more than 10 percent of the points tested shall be in error by more than $1 / 30 \mathrm{inch}$, measured on the publication scale; for maps on publication scales of $1: 20,000$ or smaller, $1 / 50$ inch. These limits of accuracy shall apply to positions of well-defined points only. Well-defined points are those that are easily visible or recoverable on the ground, such as the following: monuments or markers, such as bench marks, property boundary monuments; intersections of roads and railroads; corners of large buildings or structures (or center points of small buildings). In general, what is well-defined will also be determined by what is plottable on the scale of the map within 1/100 inch. Thus, while the intersection of two roads or property lines meeting at right angles would come within a sensible interpretation, identification of the intersection of such lines meeting at an acute angle would not be practicable within 1/100 inch. Similarly, features not identifiable upon the ground within close limits are not to be considered as test points within the limits quoted, even though their positions may be scaled closely upon the map. This class would cover timber lines and soil boundaries.

2. Vertical accuracy, as applied to contour maps on all publication scales, shall be such that not more than 10 percent of the elevations tested shall be in error by more than one-half the contour interval. In checking elevations taken from the map, the apparent vertical error may be decreased by assuming a horizontal displacement within the permissible horizontal error for a map of that scale.

3. The accuracy of any map may be tested by comparing the positions of points whose locations or elevations are shown upon it with corresponding positions as determined by surveys of a higher accuracy. Tests shall be made by the producing agency, which shall also determine which of its maps are to be tested, and the extent of such testing. 

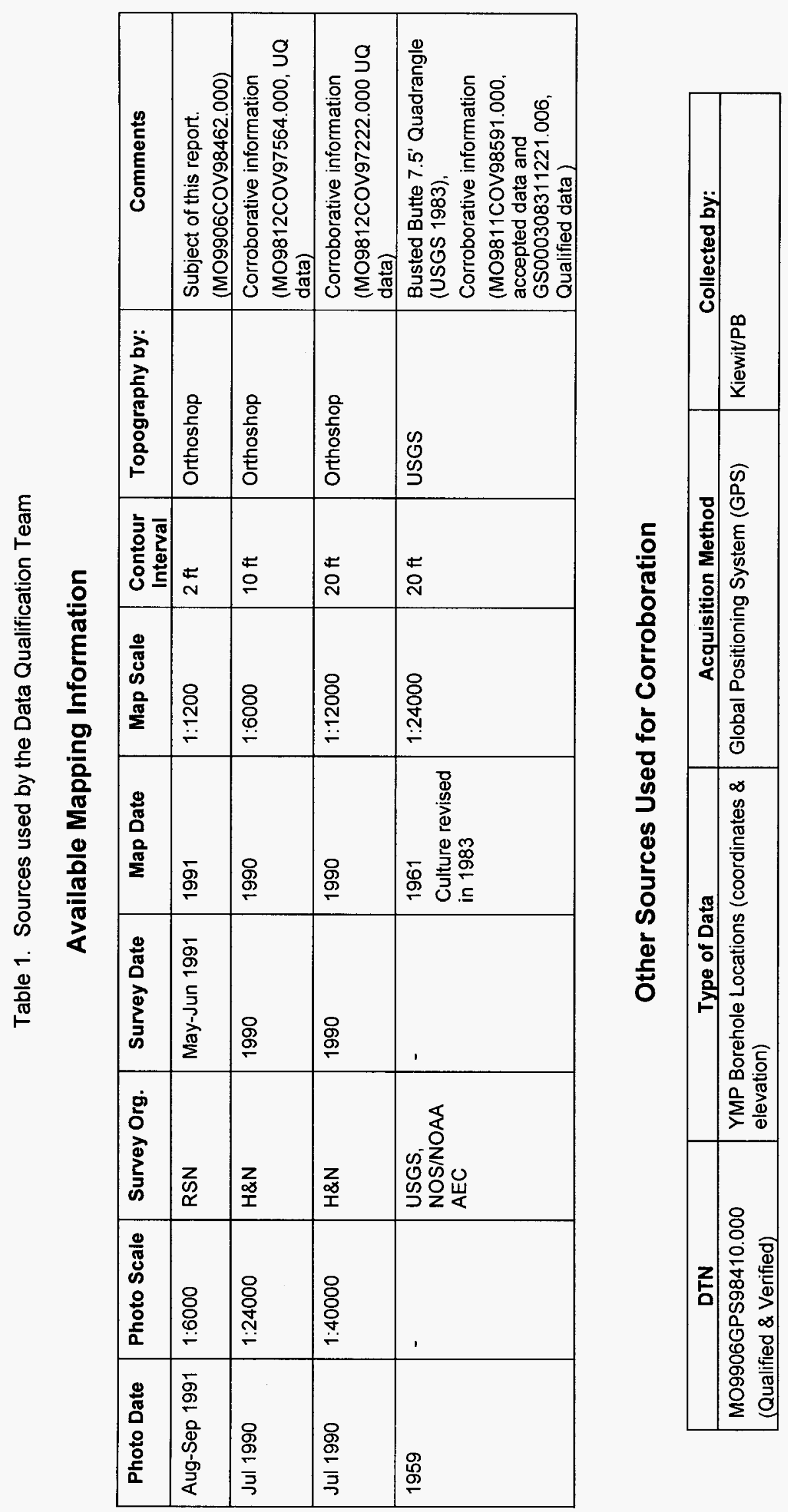


\section{EVALUATION RESULTS}

The basic approach in evaluating DTN MO9906COV98462.000 was to compare the location and elevation data for the topographic surface with other sources of similar information, and determine whether the results indicated that the mapping was sufficiently accurate for general YMP use. Two approaches were used to implement this approach. The first used a manual approach that scaled off the location of specific points that could be identified on both the subject map and one of the corroborating sources. The second approach was an electronic comparison between the terrain models (DEM) of the subject DTN and the corroborating sources. The first approach addresses the accuracy of the map in locating specific points and the second evaluates the general accuracy of the complete topographic surface.

\subsection{MANUAL POINT COMPARISON}

In this evaluation, specific points or terrain features that could be identified on both the source map and one of the corroborating sources were used to compare the location and elevation accuracy of the points. Once corresponding points were identified, the state plane coordinates of the point were manually determined using an engineer's scale. Elevation was determined by interpolating between contour lines and from indicated spot elevations. Mylar prints were used in scaling locations on the 1:1200 and 1:6000 maps. A paper copy of Busted Butte Quadrangle, Nevada-Nye County, 7.5-Minute Series (Topographic), SW/4 Topapah Spring 15' Quadrangle (USGS 1983) was used to scale locations from that source. The horizontal accuracy of the corroborating sources should range from about 16 feet for the 1:6000 scale map to about 40 feet for the 1:24000 scale map. Vertical accuracy should be about one-half contour interval.

Coordinates from a GPS survey of borehole locations (MO9906GPS98410.000) were also used as a corroborating source. The accuracy of the GPS survey can be estimated from GPS locations for first-order benchmarks in Pahrump Valley, Nevada (Kiewit/PB Survey department, Trimble GPSurvey Verson 2.2 Verification, DRC.19981020.0007 and Site Facilities Office Yucca Mountain Project Field Engineering Survey, MOL.20000125.0714) that were carried out using the same equipment. Comparison with the National Geodetic Survey locations for the benchmarks indicates an accuracy of between 0.3 and 0.5 feet for all three axes. This may be the maximum accuracy for the system under actual field conditions. Comparison of the GPS results with another GPS survey of the same point (GPS Demonstration at USW G-2 Well Site, MOL.19971113.0095) and with conventional (unqualified) survey locations in the DTNs superceded by MO9906GPS98410.000 show differences of up to 1.8 feet.

The results of the comparisons are presented in Table 2. The difference column indicates the difference between the value obtained from the 1:1200 scale maps and the corroborating source. These results are quite good considering that results depend on cumulative accuracy limitations of both sources plus the error in manually scaling distances on maps with scales as small as 1:24000. Horizontal accuracy for the 1:1200 map should be less than 3.3 feet to comply with the evaluation criteria. Vertical accuracy should be within one-half of a contour interval (1 foot).

A relatively small number of points were used in the comparison because of the difficulty in locating points that could be matched with confidence between the various sources. The best points are cultural features that appear on the 1:1200 map and another source. These include 
buildings, trailers, and some boreholes (when the analyst could see the casing/wellhead on the photography and plotted the feature on the map). Since there were relatively few features of this type in the area in 1991, the choice of points is quite limited. Other types of points add another layer of uncertainty related to whether points that correspond exactly can be identified on two sources. This is illustrated on Table 2 by the hilltop spot elevation. This point has the greatest difference of those listed on Table 2 . The difference may be due in part to the two analysts selecting somewhat different locations for the spot elevation on the respective maps in addition to the other accuracy considerations.

Table 2. Manual comparison of point data between 1:1200 scale map and corroborating sources

\begin{tabular}{|l|c|c|c|c|c|c|c|c|c|c|}
\hline & \multicolumn{2}{|c|}{$1: 1200$ Scale Map } & \multicolumn{3}{c|}{ Corroborating Source } & \multicolumn{3}{c|}{ Difference } \\
\hline \multicolumn{1}{|c|}{ Locality } & North & East & Elev. & Source & North & East & Elev. & North & East & Elev. \\
\hline UE-25 WT\#5 & 761827 & 574251 & 3558.8 & GPS & 761826.7 & 574249.8 & 3558.03 & 0.3 & 1.2 & 0.77 \\
\hline VABM Fran & 753121 & 573354 & 4110.1 & 7.5 & 753120 & 573345 & 4110 & 1 & 9 & 0.1 \\
\hline UE-25 WT\#13 & 756887 & 578840 & 3386.6 & GPS & 756885.2 & 578842.3 & 3385.86 & 1.8 & -2.3 & 0.74 \\
\hline USW H-4 & 761644 & 563910 & 4097.7 & GPS & 761644.5 & 563911.4 & 4096.17 & -0.5 & -1.4 & 1.53 \\
\hline Hilltop spot elev. & 763300 & 562612 & 4492.8 & 7.5 & 763310 & 562640 & 4492 & -10 & -28 & 0.8 \\
\hline UE-25 \#14 & 762138 & 571672 & 3654.6 & GPS & 762137.2 & 571675 & 3653.1 & 0.76 & -3 & 1.5 \\
\hline $\begin{array}{l}\text { Trailer corner on } \\
\text { equipment pad }\end{array}$ & 764707 & 566291 & 3928 & $6 K$ & 764710 & 566290 & 3930 & -3 & 1 & -2 \\
\hline USW H-5 & 766631 & 558909 & 4851.5 & GPS & 766634.1 & 558908.4 & 4851.35 & -3.12 & 0.6 & 0.15 \\
\hline $\begin{array}{l}\text { Trailer corner on } \\
\text { UE-25 A\#7 pad }\end{array}$ & 766254 & 565512 & 4005 & $6 K$ & 766254 & 565510 & 4005 & 0 & 2 & 0 \\
\hline $\begin{array}{l}\text { Trailer corner } \\
\text { near UE-25 } \\
\text { UZN\#12 }\end{array}$ & 768682 & 566154 & 3940.5 & $6 K$ & 768683 & 566160 & 3941 & -1 & -6 & -0.5 \\
\hline $\begin{array}{l}\text { Ildg. corner at } \\
\text { J-13 site }\end{array}$ & 749298 & 579861 & 3320 & $6 K$ & 749297 & 579860 & 3321 & 1 & 1 & -1 \\
\hline $\begin{array}{l}\text { Center J-13 well } \\
\text { bldg. } \\
\text { (corroborating } \\
\text { value is for well } \\
\text { location) }\end{array}$ & 749208 & 579657 & 3317.5 & GPS & 749202 & 579647.9 & 3317.4 & 6.01 & 9.09 & 0.1 \\
\hline
\end{tabular}

Corroborating data source codes: GPS $=$ Borehole survey data from MO9906GPS98410.000, 7.5' $=$ USGS Busted Butte 7.5' Quadrangle (USGS 1983), $6 K=1: 6000$ scale topographic map on orthophoto base (MO9812COV97564.000). All values are given in feet, horizontal coordinates are State Plane coordinates.

\subsection{COMPARISON OF DIGITAL ELEVATION MODELS}

Two separate approaches were used to illustrate corroboration between vertical (elevation) data for the 1:1200 scale contour dataset. Both approaches utilized ArcINFO ver. 7.2.1 (YMP baselined Q software, STN: 10033-7.2.1-00) to perform GIS analysis of the data. The first method involved the derivation and comparison of point elevations on each of the datasets listed in Table 1. The second method utilized a direct comparison of a part of the topographic surfaces from two data sets. These two surfaces were compared arithmetically and descriptive statistics of the difference between the surfaces were developed. 
Method 1-To perform an extraction of point elevations in GIS space, all of the datasets (with the exception of DTN MO9906GPS98410.000) were first converted to three-dimensional datasets called TINS (Triangular Irregular Networks). A TIN consists of a series of triangles in three-dimensional space developed through a straightforward linear interpolation between vertices used to create the contours and the elevations affiliated with each. Formatting the data in this way allows the analyst to derive elevation values at any specific point within the horizontal extent of the data regardless of whether or not that point is coincident with a contour line. The points used for comparison are part of DTN MO9906GPS98410.000 and two of the points used represent the same location as the well sites cited in Table 2. The coordinates of the point were taken from DTN MO9906GPS98410.000 and the elevation of those coordinates was determined using the TINS for each of the DEMs. The elevation of the point determined for the 1:1200 scale DEM was then compared to the elevations determined from the GPS survey and the other DEMs. The results of the elevation extractions for each dataset are included in Table 3. In considering the differences, the desired accuracy (one-half contour interval) for both sources must be considered (see Section 2). It should also be noted that the USGS topography predates the drilling of these holes and grading for the drill pads may have changed the ground-surface elevations for these coordinates in this case. A comparison of the differences indicates good agreement between all of the sources.

Method 2-An approximate $5000 \times 6000$ foot subset of the surface of the subject DTN MO9906COV98462.000 was selected for a comparison of the surfaces between two DTNs. The coordinates of the corners of the selected rectangle are shown in Table 4. The area selected covers the southern end of Midway Valley and includes areas of the valley floor as well as some small hills (see Figure 2). Total relief across the sampled area is approximately 400 feet. The area was selected as a representation of the type of terrain on which the flooding studies in BSC (2002b) would be performed. However, it is not the most conservative area that could have been selected since it does not contain the steepest slopes in the mapped area. A TIN of the surface was resampled at 5-foot intervals to create a grid or lattice dataset known in GIS terminology as a GRID or raster dataset. A 5-foot resampled GRID of the same rectangle was also generated from the DTN MO9812COV97564.000 dataset (1:6000 topography). Using a simple subtraction of co-located cells throughout the dataset, a GRID was derived which represents the absolute difference between the elevations of each 5 -foot cell in the two datasets. Figure 2 illustrates the method invoked. The summary statistics generated by ArcINFO for the cells in the difference grid are shown in Table 4. 


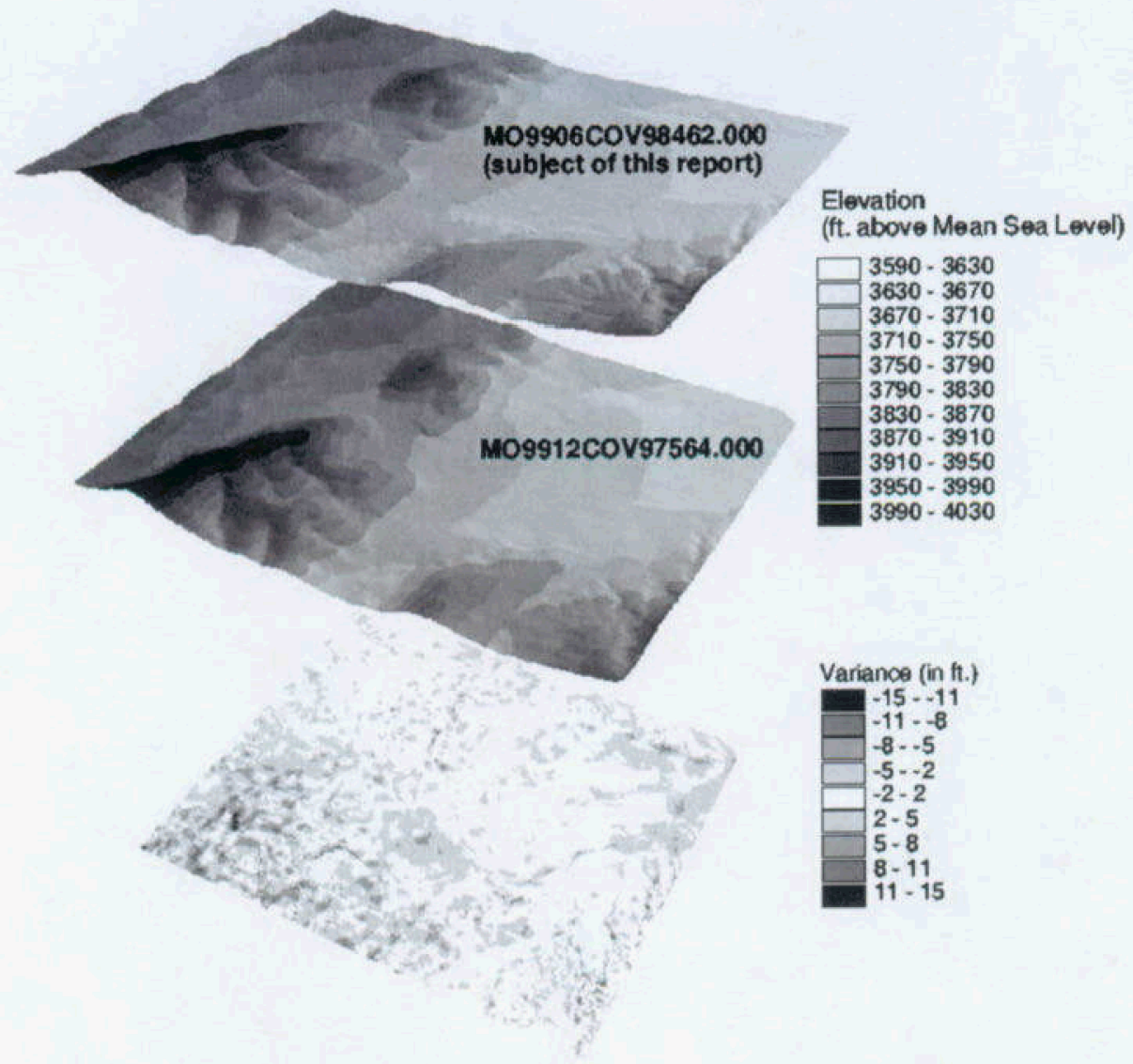

Figure 2. Visual representation of the DEM comparison process for the area identified in Table 4. The middle layer is subtracted from the upper layer to produce a representation of the difference or variance (lower layer) between the topographic surfaces represented by the two models.

Table 4. Results of DEM Comparison

Arc: describe $10 \mathrm{var2}$

\section{Cell Size $=$}

Number of Rows =

Number of Columns $=$

Number of Cells =

AREA BOUNDARY

(State Plane Coordinates)

\author{
Description of GRID 10var2 \\ 5.000 Data Type: Floating Point \\ 1044 \\ 1199 \\ 1251756
}

VARIANCE STATISTICS

(Differences between corresponding cell values in the two DEMs)

Minimum Value $=\quad-12.902$

Maximum Value $=\quad 11.368$

Mean $=\quad-1.173$

Standard Deviation $=2.228$ 
Another way to illustrate the comparison between the two DEMs is to compare topographic profiles generated from the sources. A northwest-southeast trending profile across the area in Figure 2 is shown in Figure 3 for the two surfaces. The profiles include values for 1247 of the five-foot cells and have end points at the state plane coordinates of 567126.0, 757341.9 and $573110.8,755611.0$. To compare the relative accuracy of the two profiles, the 1:6000 surface was lowered by the mean difference between the 1247 point elevations ( 1.6 feet). As illustrated in Figure 3, there is good agreement between the two surfaces. The principal area of divergence between the two surfaces occurs at inflection points (i.e., washes and hilltops). This is the result of the wider spacing of control points on the 1:6000 DEM that does not allow the software to model these areas as accurately as the 1:1200 DEM. This limitation probably explains most of the larger differences shown in Figure 2.

\section{EVALUATION CONCLUSIONS}

The conclusions of the Data Qualification Team's review of the 1:1200 scale topographic mapping (DTN MO9906COV98462.000) are presented below in terms of the four evaluation criteria presented in Section 2.1.

1 Are the data collection methods reasonable in view of standard measurement and instrumentation practice at the time the data were collected?

The survey, photographic, and photogrammetric methods used for this mapping effort represent the standard practice and standard equipment in use at the time the data were collected. The technique of generating topographic maps from aerial photography has been in general use since the late 1930 s and the general theory involved in processes used is unchanged. The data collection and reduction methods used by the three participants in the project represent the standard practice for generating this type of information in 1991 and also at the present time. The equipment for the ground control survey (Wild TC1600 theodolite), the camera used for the photography (Wild RC-10), and the photogrammetric equipment (Wild Aviolyt BC1 \& BC2 and associated equipment) used by the Orthoshop to produce the maps and digital elevation model are considered to be the standard type of equipment that would have been used for this type of work in 1991. Wild Heerbrugg, Ltd. and its successors is a leading Swiss manufacturer of optics and equipment that has been producing theodolites since 1921, aerial cameras since 1929, and stereoplotters and related equipment since 1932.

2. Are the qualifications of the personnel or organizations generating the data comparable to qualification requirements of personnel generating similar data under the approved $10 \mathrm{CFR}$ 63, Subpart G, program?

The proposal submitted by The Orthoshop-Tucson included the qualifications of the company and summaries of the education and experience of the staff involved in the work. The company has been in the mapping industry since 1980 with offices in Canada, Arizona (opened in 1987), and Mexico. The proposal listed several prior projects for government agencies and private concerns with similar scope to the present project. Quality control procedures were also outlined that covered equipment calibration, checking procedures for detecting errors and mismatches with the ground control. The staff identified in the proposal had education/certifications in fields related to map preparation (e.g., surveying, civil engineering, geology) and photography. The 


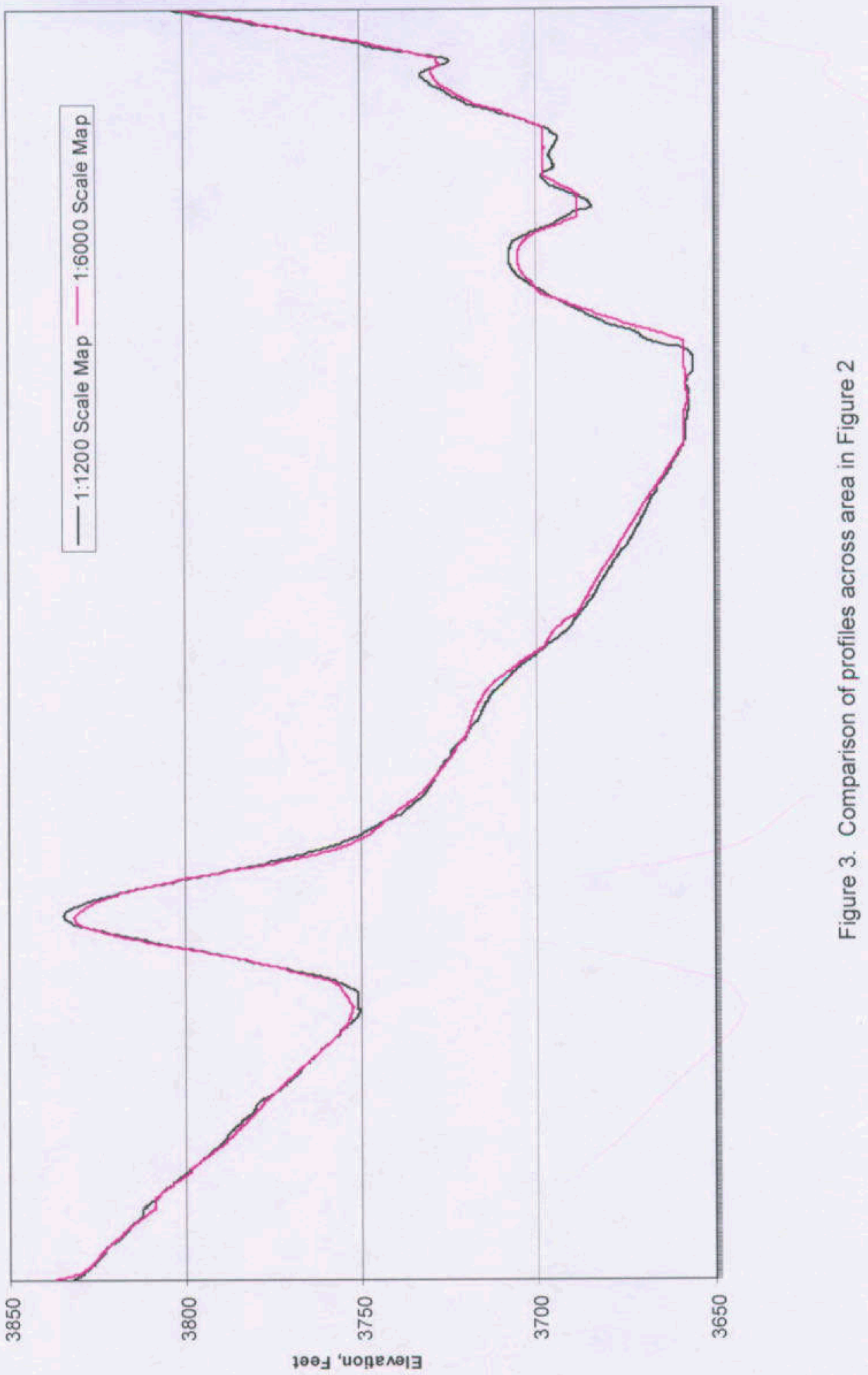

TDR-WHS-CI-000001 REV 00 
staff also had significant prior experience with the equipment to be used on the project from prior mapping projects. The Data Qualification Team has concluded that company and its staff have qualifications that would meet the requirements for generating similar products under the approved 10 CFR 63, Subpart G, program.

The survey group from RSN was already qualified to perform surveys under the approved 10 CFR 60, Subpart G, program when the work was done in 1991.

3. Are these data, or similarly collected data, generally accepted by the technical community for use in non-project applications?

Detailed topographic maps produced from aerial photographs are a generally accepted tool used in civil construction (e.g., dams, highways), land use planning, and for scientific purposes (e.g., geologic mapping). The method has been virtually the only method used for producing topographic maps for several decades.

\section{Does analysis of comparable qualified and unqualified data sets indicate a reasonable level of accuracy for the mapping products?}

The comparison of the 1:1200 scale mapping information to other data sets covering the Midway Valley area in Sections 3.1 and 3.2 is basically intended to address this question. The absolute accuracy of the 1:1200 mapping is addressed by the results presented in Tables 2 and 3. Any attempt to address absolute accuracy is dependent on a comparison with another source to determine the absolute accuracy of points on the subject source relative to the "true" location of those points. The problem with this approach is that the corroborating source will also have accuracy limits that affect any such comparison (see Figure 1). This is particularly true when the corroborating source is less accurate than the subject source. Depending on the geometry of the two source locations relative to the "true" location (which is actually fictional and cannot be known), the accuracy of the corroborating source may either increase or decrease the apparent accuracy of the subject source when the differences between the two sources are calculated. This evaluation concentrates on the comparison between the 1:1200 mapping and the GPS survey of borehole locations since the GPS survey is the corroborating source that most closely approximates the target accuracy of the 1:1200 mapping. When the elevation differences for these two sources shown in Tables 2 and 3 are reviewed, an interesting pattern emerges. All of the differences are positive (i.e., the 1:1200 elevation is always higher than the corresponding GPS elevation). Normally, one would expect to see an approximately equal number of positive and negative differences in such a comparison. This might indicate a systematic bias in one of the two sources. The mean of the 16 differences in Tables 2 and 3 is very close to one foot $(+0.997$ feet) for this comparison with maximum difference being 1.54 feet. This compares to the mean difference between the DEM surfaces for the 1:6000 and 1:1200 scale mapping shown in Table 4, which also indicates a one-foot mean difference ( -1.173 feet), however, in the opposite direction. With a sufficient number of samples, the variations caused by accuracy limitations should cancel out and cause the mean difference to trend toward a zero value. The departure of the mean values from zero then gives some indication of the relative absolute accuracy of the various sources. 
While it is possible to make a geometric argument that the results of the GPS comparison could indicate an absolute average vertical accuracy for the 1:1200 scale mapping of 1.0 to 1.5 feet, the limited number of high accuracy corroborating points available makes it difficult to make a strong case. The Data Qualification Team feels that it is more defensible to estimate the vertical accuracy limits on point elevations from the 1:1200 scale mapping at approximately \pm 2 feet. Absolute horizontal accuracy can be estimated by reviewing the differences between horizontal GPS and 1:1200 locations in Table 2. There is no indication of a systematic horizontal error, since there are an equal number of positive and negative differences. Horizontal differences range from 0.3 to 3.1 feet (the $\mathrm{J}-13$ well location was not used since a corresponding point was not available). These results need to be viewed with caution because of the small sample size and the additional error introduced in manual scaling. As a result, the Data Qualification Team feels that it can only estimate the horizontal accuracy limits on point locations from the 1:1200 mapping at \pm 4 feet. The mapping may be of higher accuracy than these estimates but additional testing (a ground survey) would be required to demonstrate this. The results of the evaluation indicate that the 1:1200 mapping cannot be shown to meet the evaluation criteria listed in Section 2.1 ( \pm 1 foot vertical accuracy and \pm 3.3 feet horizontal accuracy). This does not necessarily mean that the mapping cannot be used for quality affecting work, but does mean that absolute locations taken from the mapping are subject to larger accuracy limits than might normally be expected for mapping of this type.

Relative accuracy is addressed by the comparisons between the two DEMs in Section 3.2. The comparisons in Figures 2 and 3 consider how well significant portions of the surface represented by the DEMs match with each other and, by extension, are accurate representations of the terrain. The two figures clearly show that the two surfaces match closely and are representing the same terrain features. In this sense, the two DEMs are mutually corroborating as representations of the actual terrain. These results and the results from Tables 2 and 3 all indicate that the 1:1200 scale mapping provides a representation of the terrain with reasonable relative accuracy.

\section{RECOMMENDATIONS}

The Data Qualification Team found that the 1:1200 scale topographic mapping identified by DTN MO9906COV98462.000 is qualified for general use on the YMP. The Data Qualification Team found that the accuracy of the final product is reasonable for a commercial product of this type. Absolute map accuracy (i.e., accuracy relative to standard coordinate and reference systems) is good, but could not be demonstrated to be within national map accuracy standards. This is primarily because of the limited availability of corroborating points with equal or greater accuracy than the subject mapping. The Data Qualification Team recommends that the Automated Technical Data Tracking entry for this DTN include a statement on the estimated absolute accuracy limits of the mapping in the comments section. The absolute accuracy limits estimated by the Data Qualification Team on the basis of the available information are \pm 2 feet vertical and \pm 4 feet horizontal.

Relative map accuracy (i.e., the location/elevation accuracy of different points on the map when compared to each other and as a representation of actual conditions on the ground) is very good based on comparisons with other representations of the terrain. The Data Qualification Team recommends that this mapping is suitable for all uses requiring standard topographic mapping. 
Users should be aware of the limitations of this type of product when considering its use. Applications that require highly precise location information for specific points (absolute accuracy) would be better served by standard surveying methods. On the other hand, applications that require a representation of the terrain over a significant area (such as the flood modeling in BSC 2002b) can use topographic information such as that contained in the subject DTN.

\section{REFERENCES}

\subsection{DOCUMENTS CITED}

BSC (Bechtel SAIC Company, LLC) 2002a. Data Qualification Plan for 1991 Topographic Maps 1:1200 Scale for Use on the Yucca Mountain Project, DQP-WHS-CI-000001, REV 00. Las Vegas, Nevada: ACC: MOL.20020513.0374

BSC (Bechtel SAIC Company, LLC) 2002b. Preliminary Hydrologic Engineering Studies for the North Portal Pad and Vicinity. ANL-EBS-MD-000060 REV 00. Las Vegas, Nevada: In prep.

DOE (U.S. Department of Energy) 2000. Quality Assurance Requirements and Description. DOE/RW-0333P, Rev. 11. Washington, D.C.: U.S. Department of Energy, Office of Civilian Radioactive Waste Management. ACC: MOL.20020506.0915

\subsection{CODES, STANDARDS, REGULATIONS, AND PROCEDURES}

AP-3.15Q, Rev. 3, ICN 2. Managing Technical Product Inputs. Washington, D.C.: U.S. Department of Energy, Office of Civilian Radioactive Waste Management. ACC: MOL.20020423.0155

AP-SIII.2Q, Rev. 0, ICN 3. Qualification of Unqualified Data and the Documentation of Rationale for Accepted Data. Washington, D.C.: U.S. Department of Energy, Office of Civilian Radioactive Waste Management. ACC: MOL.20001002.0152

\subsection{SOURCE DATA, LISTED BY DATA TRACKING NUMBER}

MO9906COV98462.000. Coverage: TOPO2FTS. Submittal date: 06/07/1999.

MO9811COV98591.000. Coverage: TOPO20S. Submittal date: 11/09/1998.

MO9906GPS98410.000. Yucca Mountain Project (YMP) Borehole Locations. Submittal date: 06/23/1999.

MO9812COV97564.000. Coverage: TOPO10S. Submittal date: 12/14/1998.

MO9812COV97222.000. Coverage: YM12KDEMS. Submittal date: 12/16/1998. 
GS000308311221.006. Merged USGS Digital Elevation Model from Topopah Spring West and Busted Butte 7.5' DEMS. Submittal date: 03/02/2000.

\subsection{SOFTWARE}

CRWMS 2000, Software Code: ARC/INFO 7.2.1, STN: 10033-7.2.1-00.

\subsection{MAP PRODUCTS}

DOE (U.S. Department of Energy) 1997. Yucca Mountain Site Characterization Project Site Atlas 1997. Washington, D.C.: U.S. Department of Energy. ACC: MOL.19980623.0385.

USGS (U.S. Geological Survey) 1983. Busted Butte Quadrangle, Nevada-Nye County, 7.5Minute Series (Topographic), SW/4 Topapah Spring 15' Quadrangle. Reston, Virginia: U.S. Geological Survey. ACC: MOL.19970723.0260.

\subsection{REPORTS}

Job Package 91-8, 07-26-91 Aerial Mapping. ACC: MOL.19980123.0864

QAGR (Quality Assurance Grading Report) RSN-GR-022, 05-06-91, Aerial Mapping of a Portion of the Yucca Mountain Site Characterization Project Area. ACC: NNA.19910520.0034.

\subsection{SURVEYS}

GPS Demonstration at USWG-2 Well Site. ACC: MOL.19971113.0095.

Keiwit/PB Survey Department, Trimble GPSurvey Version 2.2 Verification. ACC: DRC.19981020.0007.

Site Facilities Office Yucca Mountain Project Field Engineering Survey. ACC:

MO9906GPS98410.000. 